\title{
ION EXCHANGE EQUILIBRIUM FOR SOME UNI-UNIVALENT AND UNI-DIVALENT REACTION SYSTEMS USING STRONGLY BASIC ANION EXCHANGE RESIN DUOLITE A-102 D
}

\author{
R.S. Lokhande, P.U. Singare* and A.R. Kolte \\ Department of Chemistry, University of Mumbai, Vidyanagri, Santacruz, Mumbai-400 098, \\ India
}

(Received December 8, 2006; revised July 22, 2007)

\begin{abstract}
The study on thermodynamics of ion exchange equilibrium for uni-univalent $\mathrm{Cl}^{-} / \mathrm{I}, \mathrm{Cl}^{-} / \mathrm{Br}^{-}$, and uni-divalent $\mathrm{Cl}^{-} / \mathrm{SO}_{4}{ }^{2-}, \mathrm{Cl}^{-} / \mathrm{C}_{2} \mathrm{O}_{4}{ }^{2-}$ reaction systems was carried out using ion exchange resin Duolite A-102 D. The equilibrium constant $\mathrm{K}$ was calculated by taking into account the activity coefficient of ions both in solution as well as in the resin phase. The $\mathrm{K}$ values calculated for uni-univalent and uni-divalent anion exchange reaction systems was observed to increase with rise in temperature, indicating the endothermic exchange reactions having enthalpy values of $13.7,38.0,23.9,22.9 \mathrm{~kJ} / \mathrm{mol}$, respectively.
\end{abstract}

KEY WORDS: Duolite A-102 D ion exchange resin, Equilibrium constant, Endothermic ion exchange reaction, Enthalpy, Thermodynamic study

\section{INTRODUCTION}

For proper selection of ion exchange resin in a particular technical application, it is essential to have adequate knowledge regarding their physical and chemical properties, which forms the complementary part of resin characterization study. Extensive work was done by previous researchers to study the properties of the ion exchange resins [1-3], to generate thermodynamic data [4-7] related to various uni-univalent and heterovalent ion exchange systems. Recently theories explaining ion exchange equilibrium [8] between the resin phase and solution was developed. A number of researchers carried out equilibrium studies [9-31], extending over a wide range of composition of solution and resin phase. Attempts were also made to study the temperature effect on cation exchange systems for computing the thermodynamic equilibrium constants [9-23]. However very little work was carried out to study the equilibrium of anion exchange systems [12, 24-29]. Therefore in the present investigation attempts were made to study the temperature effect on uni-univalent and uni-divalent anion exchange reaction equilibrium, the result of which will be of considerable use in qualitatively assessing an ion exchange resin for its utility in a stipulated exchange process.

\section{EXPERIMENTAL}

The ion exchange resin Duolite A-102 D as supplied by the manufacturer (Auchtel Products Ltd., Mumbai, India) was a strongly basic quaternary ammonium $-\mathrm{N}-\left(\mathrm{CH}_{3}\right)^{+}$anion exchanger in chloride form containing $8 \%$ styrene divinyl benzene of 20-50 mesh size. For present investigation, the resin grains of 30-40 mesh size were used. The soluble impurities of the resin were removed by repeated Soxhlet extraction using water and occasionally with distilled methanol to remove non-polymerized organic impurities. In order to ensure complete conversion of resins in chloride form, the resins were conditioned with $10 \%$ potassium chloride solution in a conditioning column. The resins were washed with distilled deionised water until the washings 
were free from chloride ions. The resins in chloride form were air dried over $\mathrm{P}_{2} \mathrm{O}_{5}$ and used for further studies.

\section{(a) Study of uni-univalent ion exchange equilibrium}

Ion exchange resins $(0.500 \mathrm{~g})$ in chloride form were equilibrated with iodide ion solution of different concentrations at a constant temperature of $30.0^{\circ} \mathrm{C}$ for $4 \mathrm{~h}$. From the results of kinetics study reported earlier $[32,33]$; it was observed that this duration was adequate to attain the ion exchange equilibrium. After $4 \mathrm{~h}$, the iodide ion solutions in equilibrium with ion exchange resins in chloride form were analyzed for their chloride and iodide ion concentrations by potentiometric titration with standard $0.1 \mathrm{M}$ silver nitrate solution. From the results the equilibrium constant $\mathrm{K}$ for the reaction

$$
\mathrm{R}-\mathrm{Cl}+\mathrm{I}_{(\mathrm{aq})}^{-} \rightleftharpoons \mathrm{R}-\mathrm{I}+\mathrm{Cl}_{(\mathrm{aq})}^{-}
$$

was determined at $30.0{ }^{0} \mathrm{C}$. The equilibrium constants $\mathrm{K}$ for the above $\mathrm{Cl}^{-} / \mathrm{I}$ system was determined for different temperatures in the range of $30.0{ }^{\circ} \mathrm{C}$ to $45.0{ }^{\circ} \mathrm{C}$.

Similar studies were carried out for $\mathrm{Cl}^{-} / \mathrm{Br}^{-}$system in the same temperature range, to study the equilibrium constant for the reaction

$$
\mathrm{R}-\mathrm{Cl}+\mathrm{Br}^{-}(\mathrm{aq}) \quad \mathrm{R}-\mathrm{Br}+\mathrm{Cl}^{-}{ }_{(\mathrm{aq})}
$$

\section{(b) Study of uni-divalent ion exchange equilibrium}

Ion exchange resins $(0.500 \mathrm{~g})$ in chloride form were equilibrated with sulfate ion solution of known initial concentration at a constant temperature of $30.0{ }^{\circ} \mathrm{C}$ for $4 \mathrm{~h}$, which was sufficient time to attain the ion exchange equilibrium. After $4 \mathrm{~h}$ the concentration of chloride ions exchanged in to the solution was estimated by potentiometric titration against standard $0.1 \mathrm{M}$ silver nitrate solution using a semi-micro burette having an accuracy of $0.02 \mathrm{~mL}$. Since it is known that one mole of sulfate ions replaces two moles of chloride ions and from the knowledge of chloride ions in the solution at equilibrium, the amount of sulfate ions exchanged on the resin was calculated. After knowing the initial concentration of sulfate ions in the solution and the amount of sulfate ions exchanged on the resin, the equilibrium concentration of sulfate ions in the solution was calculated. Further from the known resin capacity and the amount of sulfate ions replacing the chloride ions on the resin, the amount of chloride ions remaining on the resin was calculated. Having thus known the equilibrium concentrations of chloride and sulfate ions in the solution and in the resin phase, the apparent equilibrium constant $\mathrm{K}_{\text {app. }}$ for the reaction

$$
2 \mathrm{R}-\mathrm{Cl}+\mathrm{SO}_{4}{ }^{2-}{ }_{(\mathrm{aq})} \rightleftharpoons \mathrm{R}_{2} \mathrm{SO}_{4}+2 \mathrm{Cl}_{(\text {(a) }}^{-}
$$

was calculated. The same experiment was repeated for different initial concentrations of sulfate ions in the temperature range of $30.0{ }^{0} \mathrm{C}$ to $45.0{ }^{\circ} \mathrm{C}$ to calculate the apparent equilibrium constant $\mathrm{K}_{\text {app }}$ for the above $\mathrm{Cl}^{-} / \mathrm{SO}_{4}{ }^{2-}$ exchange.

Similar experiment was performed for $\mathrm{Cl}^{-} / \mathrm{C}_{2} \mathrm{O}_{4}{ }^{2-}$ system by equilibrating ion exchange resins in chloride form with oxalate ion solution of different concentrations, and apparent equilibrium constants $\mathrm{K}_{\text {app. }}$ for the reaction

$$
2 \mathrm{R}-\mathrm{Cl}+\mathrm{C}_{2} \mathrm{O}_{4}{ }^{2-}{ }_{(\text {aq })} \rightleftharpoons \quad \mathrm{R}_{2} \mathrm{C}_{2} \mathrm{O}_{4}+2 \mathrm{Cl}^{-}{ }_{(\mathrm{aq})}
$$

was calculated in the same temperature range. 
The iodide, bromide, sulfate and oxalate ion solutions used in the entire experimental work were prepared by dissolving their corresponding potassium salts (Analytical grade) in distilled deionised water.

\section{RESULTS AND DISCUSSION}

The equilibrium constants for the reactions (1 and 2) can be given by the expression

$$
\mathrm{K}=\frac{\mathrm{C}_{\mathrm{R}-\mathrm{X} \cdot \mathrm{C}_{\mathrm{Cl}}{ }^{-}}}{\left(\mathrm{A}-\mathrm{C}_{\mathrm{R}-\mathrm{X}}\right) \cdot \mathrm{C}_{\mathrm{X}}{ }^{-}}
$$

where $\mathrm{A}$ is the ion exchange capacity of the resin, $\mathrm{x}^{-}$represents $\mathrm{I}^{-}$or $\mathrm{Br}^{-}$ions.

For different concentrations of $\mathrm{x}^{-}$ions in solution at a given temperature, $\mathrm{K}$ values were calculated from which average value of $\mathrm{K}$ for that set of experiment was calculated (Tables 1 , 2). Similar values of $\mathrm{K}$ were calculated for both $\mathrm{Cl}^{-} / \mathrm{I}^{-}$and $\mathrm{Cl}^{-} / \mathrm{Br}^{-}$systems for different temperatures (Tables 3, 4).

Table 1. Equilibrium constant for the ion exchange reaction: $\mathrm{R}-\mathrm{Cl}+\mathrm{I}_{\mathrm{aq}} \leftrightarrows \mathrm{R}-\mathrm{I}+\mathrm{Cl}^{-}$aq in Duolite A-102 D (Amount of the ion exchange resin in chloride form $=0.500 \mathrm{~g}$, ion exchange capacity $=1.2$ meq. $/ 0.5 \mathrm{~g}$, volume of iodide ion solution $=50.0 \mathrm{~mL}$, temperature $=30.0^{\circ} \mathrm{C}$ ).

\begin{tabular}{|c|c|c|c|c|c|c|}
\hline System & $\begin{array}{c}\text { Initial conc. } \\
\text { of iodide } \\
\text { ion (M) }\end{array}$ & $\begin{array}{c}\text { Final conc. } \\
\text { of iodide } \\
\text { ions (M) } \mathrm{C}_{\mathrm{I}}^{-}\end{array}$ & $\begin{array}{c}\text { Change } \\
\text { in iodide } \\
\text { ion conc. }\end{array}$ & $\begin{array}{c}\text { Conc. of } \mathrm{Cl}^{-} \text {ions } \\
\text { exchanged } \\
\text { (M) } \mathrm{C}_{\mathrm{Cl}}^{-}\end{array}$ & $\begin{array}{c}\text { Amount of iodide ions } \\
\text { exchanged on the resin } \\
\text { meq./0.5 g } \mathrm{C}_{\mathrm{RI}}\end{array}$ & $\begin{array}{c}\text { Equilibrium } \\
\text { constant } \mathrm{K}\end{array}$ \\
\hline 1 & 0.02 & 0.0030 & 0.0170 & 0.0169 & 0.850 & 13.7 \\
\hline 2 & 0.03 & 0.0094 & 0.0206 & 0.0206 & 1.030 & 13.3 \\
\hline 3 & 0.04 & 0.0180 & 0.0220 & 0.0219 & 1.100 & 13.4 \\
\hline 4 & 0.05 & 0.0274 & 0.0226 & 0.0225 & 1.130 & 13.3 \\
\hline 5 & 0.06 & 0.0371 & 0.0229 & 0.0231 & 1.145 & 13.0 \\
\hline 6 & 0.08 & 0.0567 & 0.0233 & 0.0235 & 1.165 & 13.8 \\
\hline
\end{tabular}

Average equilibrium constant $(\mathrm{K})=13.4$.

Table 2. Equilibrium constant for the ion exchange reaction: $\mathrm{R}-\mathrm{Cl}+\mathrm{Br}_{(\mathrm{aq})}^{-} \leftrightarrows \mathrm{R}-\mathrm{Br}+\mathrm{Cl}_{(\text {(aq) }}^{-}$in Duolite $\mathrm{A}-102 \mathrm{D}$ (Amount of the ion exchange resin in chloride form $=0.500 \mathrm{~g}$, ion exchange capacity $=$ $1.2 \mathrm{meq} / / 0.5 \mathrm{~g}$, volume of bromide ion solution $=50.0 \mathrm{~mL}$, temperature $=30.0{ }^{\circ} \mathrm{C}$ ).

\begin{tabular}{|c|c|c|c|c|c|c|}
\hline System & $\begin{array}{c}\text { Initial conc. } \\
\text { of } \mathrm{Br}^{-} \text {ion } \\
\text { solution } \\
(\mathrm{M})\end{array}$ & $\begin{array}{c}\text { Final conc. } \\
\text { of Br ion } \\
\text { solution } \\
(\mathrm{M}) \mathrm{C}_{\mathrm{Br}}^{-}\end{array}$ & $\begin{array}{c}\text { Change in } \\
\text { bromide ion } \\
\text { conc. (M) }\end{array}$ & $\begin{array}{c}\text { Conc. of } \\
\text { chloride ion } \\
\text { exchanged } \\
(\mathrm{M}) \mathrm{C}_{\mathrm{Cl}}^{-}\end{array}$ & $\begin{array}{c}\text { Amount of Br ions } \\
\text { exchanged on the } \\
\text { resin meq./0.500g } \\
\mathrm{C}_{\mathrm{R}-\mathrm{Br}}\end{array}$ & $\begin{array}{c}\text { Equilibrium } \\
\text { constant } \mathrm{K}\end{array}$ \\
\hline 1 & 0.02 & 0.0060 & 0.0140 & 0.0139 & 0.700 & 3.2 \\
\hline 2 & 0.03 & 0.0130 & 0.0170 & 0.0171 & 0.850 & 3.2 \\
\hline 3 & 0.04 & 0.0211 & 0.0189 & 0.0184 & 0.945 & 3.2 \\
\hline 4 & 0.05 & 0.0301 & 0.0199 & 0.0200 & 0.995 & 3.2 \\
\hline 5 & 0.06 & 0.0393 & 0.0207 & 0.0206 & 1.035 & 3.3 \\
\hline 6 & 0.08 & 0.0585 & 0.0215 & 0.0217 & 1.075 & 3.2 \\
\hline
\end{tabular}

Average equilibrium constant $(\mathrm{K})=3.2$. 
Table 3. Effect of temperature on equilibrium constant for uni-univalent ion exchange reaction: $\mathrm{R}-\mathrm{Cl}+\mathrm{I}_{(\mathrm{aq})}^{-} \leftrightarrows \mathrm{R}-\mathrm{I}+\mathrm{Cl}_{(\mathrm{aq})}^{-}$in Duolite A-102 D

(Amount of ion exchange resin in chloride form $=0.500 \mathrm{~g}$, volume of $\mathrm{I}^{-}$ion solution $=50 \mathrm{~mL}$ ).

\begin{tabular}{|l|l|l|l|l|}
\hline Temperature ${ }^{\mathrm{O}} \mathrm{C}$ & 30.0 & 35.0 & 40.0 & 45.0 \\
\hline Equilibrium constant (K) & 13.4 & 14.5 & 15.6 & 17.1 \\
\hline
\end{tabular}

Slope of graph $\log \mathrm{K}$ vs. temperature (Kelvin) $1 / \mathrm{T} \times 10^{-3}=-718.01$, enthalpy change of the ion exchange reaction $=13.7 \mathrm{~kJ} / \mathrm{mol}$.

Table 4. Effect of temperature on equilibrium constant for uni-univalent ion exchange reaction:

$\mathrm{R}-\mathrm{Cl}+\mathrm{Br}_{(\mathrm{aq})}^{-} \leftrightarrows \mathrm{R}-\mathrm{Br}+\mathrm{Cl}_{(\mathrm{aq})}^{-}$in Duolite A-102 D

(Amount of ion exchange resin in chloride form $=0.500 \mathrm{~g}$, volume of $\mathrm{Br}^{-}$ion solution $=50 \mathrm{~mL}$ ).

\begin{tabular}{|l|l|l|l|l|}
\hline Temperature ${ }^{\mathrm{O}} \mathrm{C}$ & 30.0 & 35.0 & 40.0 & 45.0 \\
\hline Equilibrium constant (K) & 3.2 & 4.0 & 5.1 & 6.3 \\
\hline
\end{tabular}

Slope of graph $\log \mathrm{K} v s$. temperature (Kelvin) $1 / \mathrm{T} \times 10^{-3}=-1988.15$, Enthalpy change of the ion exchange reaction $=38.0 \mathrm{~kJ} / \mathrm{mol}$.

The equilibrium constants for the uni-divalent ion exchange reactions $(3,4)$ would be given by the expression

$\mathrm{K}=\frac{\left(\alpha_{\mathrm{R} 2 \mathrm{y}}\right)\left(\alpha_{\mathrm{X}}^{-}\right)^{2}{ }_{\mathrm{aq}}}{\left(\alpha_{\mathrm{RX}}\right)^{2}\left(\alpha_{\mathrm{y}}{ }^{2-}\right)_{\mathrm{aq}}}$

where $\alpha$ is the activities of various species, $\mathrm{x}=\mathrm{Cl}^{-}$ion and $\mathrm{y}=\mathrm{SO}_{4}{ }^{2-}$ or $\mathrm{C}_{2} \mathrm{O}_{4}{ }^{2-}$ ions. In the above expression, the activities of $\mathrm{x}$ and $\mathrm{y}$ in the aqueous solution are obtained from their respective concentrations and activity coefficients derived from Debye Huckel limiting law. As regards the activities of the two ions in the resin are concerned, the situation is different. Ordinarily the activity should be obtained as a product of concentration and the activity coefficient. In lieu of the concentration of the ions in the resin, their respective amounts in milliequivalents can be used, as shown by the satisfactory results obtained for the equilibrium constant of uni-univalent exchange reactions. On this basis, the equilibrium constant would be given by the expression

$\mathrm{K}=\frac{\left(\mathrm{C}_{\mathrm{R} 2 \mathrm{y}} \cdot \gamma_{\mathrm{R} 2 \mathrm{y}}\right)\left(\mathrm{C}_{\mathrm{x}}^{-} \cdot \gamma_{\mathrm{x}}{ }^{-}\right)^{2}}{\left(\mathrm{C}_{\mathrm{Rx}} \cdot \gamma_{\mathrm{Rx}}\right)^{2}\left(\mathrm{C}_{\mathrm{y}}{ }^{2-} \cdot \gamma_{\mathrm{y}}{ }^{2-}\right)}$

where $\gamma$ is the activity coefficient of ions in the solution at equilibrium.

In this expression, the concentrations of ions in the resin phase in terms of their amounts in milliequivalents are known while their individual activity coefficients i.e. $\gamma_{\mathrm{R} 2 \mathrm{y}}$ and $\gamma_{\mathrm{Rx}}$ are not known. Indeed, it appears that there is no way for evaluating them individually. In case of uniunivalent exchange reactions, they could be ignored because they where likely to be of the same magnitude (being for univalent ions) and in the expression for equilibrium their ratio is nearly one. In the present case for uni-divalent exchange however, the activity coefficients can not be ignored because in the expression for the equilibrium constant they appear as $\gamma_{\mathrm{R} 2 \mathrm{y}} /\left(\gamma_{\mathrm{Rx}}\right)^{2}$. Since $\gamma_{\mathrm{R} 2 \mathrm{y}}$ and $\gamma_{\mathrm{Rx}}$ are likely to vary with the concentration of the ions $\mathrm{y}$ and $\mathrm{x}$ in the resin, the above mentioned quantity is also likely to vary with the concentrations of the ions in the resin. This is confirmed from the fact that the equilibrium constant as calculated from the expression

$\mathrm{K}_{\mathrm{app}}=\frac{\left(\mathrm{C}_{\mathrm{R} 2 \mathrm{Y}}\right)\left(\mathrm{C}_{\mathrm{X}}{ }^{-}\right)^{2}\left(\gamma_{\mathrm{X}}{ }^{-}\right)^{2}}{\left(\mathrm{C}_{\mathrm{RX}}\right)^{2}\left(\mathrm{C}_{\mathrm{Y}}{ }^{2-}\right)\left(\gamma_{\mathrm{Y}^{2-}}{ }^{2-}\right.}$

varies with the concentration of the ions in the resin (Tables 5,6).

Bull. Chem. Soc. Ethiop. 2008, 22(1) 
Table 5. Equilibrium constants for the uni-divalent ion exchange reaction:

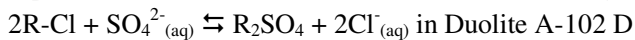

(Amount of the ion exchange resin in chloride form $=0.500 \mathrm{~g}$, volume of the sulfate ion solution $=$ $100 \mathrm{~mL}$, temperature $=30.0{ }^{\circ} \mathrm{C}$ ).

\begin{tabular}{|c|c|c|c|c|c|c|c|}
\hline \multirow[t]{2}{*}{$\begin{array}{l}\text { Initial conc. of } \mathrm{SO}_{4}{ }^{2-} \\
\text { ions in solution }(\mathrm{M})\end{array}$} & \multicolumn{2}{|c|}{$\begin{array}{l}\text { Equilibrium conc. in } \\
\text { solution (M) }\end{array}$} & \multicolumn{2}{|c|}{$\begin{array}{l}\text { Amount of the ions on } \\
\text { the resin meq. } / 0.500 \mathrm{~g}\end{array}$} & \multirow{2}{*}{$\begin{array}{c}\text { Apparent } \\
\text { equilibrium } \\
\text { constant } \mathrm{K}_{\text {app }}\end{array}$} & \multirow{2}{*}{$\frac{\mathrm{K}_{\text {std }}}{\mathrm{K}_{\text {app }}}$} & \multirow{2}{*}{$=\frac{\left(\gamma_{\mathrm{R} 2 \mathrm{SO} 4}\right)}{\left(\gamma_{\mathrm{RCl}}\right)^{2}}$} \\
\hline & $\mathrm{C}_{\mathrm{Cl}}^{-}$ & $\mathrm{C}_{\mathrm{SO} 4}{ }^{2-}$ & $\mathrm{C}_{\mathrm{RCl}}$ & $\mathrm{C}_{\mathrm{R} 2 \mathrm{SO} 4}$ & & & \\
\hline 0.007 & 0.0074 & 0.0024 & 0.46 & 0.370 & 30.1 & & 1.14 \\
\hline 0.008 & 0.0077 & 0.0031 & 0.43 & 0.385 & 29.3 & & 1.18 \\
\hline 0.009 & 0.0080 & 0.0041 & 0.40 & 0.400 & 27.9 & & 1.26 \\
\hline 0.010 & 0.0082 & 0.0051 & 0.38 & 0.410 & 26.1 & & 1.31 \\
\hline 0.015 & 0.0088 & 0.0112 & 0.32 & 0.440 & 18.3 & & 1.83 \\
\hline 0.020 & 0.0090 & 0.0156 & 0.30 & 0.450 & 14.9 & & 2.38 \\
\hline 0.030 & 0.0093 & 0.0264 & 0.27 & 0.462 & 10.3 & & 3.49 \\
\hline 0.050 & 0.0098 & 0.0457 & 0.22 & 0.490 & 8.7 & & 3.93 \\
\hline
\end{tabular}

Equilibrium constant in standard state $\left(\mathrm{K}_{\mathrm{std}}\right)=32.7$.

Table 6. Equilibrium constants for the uni-divalent ion exchange reaction:

$2 \mathrm{R}-\mathrm{Cl}+\mathrm{C}_{2} \mathrm{O}_{4}{ }^{2-}{ }_{(\mathrm{aq})} \leftrightarrows \mathrm{R}_{2} \mathrm{C}_{2} \mathrm{O}_{4}+2 \mathrm{Cl}^{-}(\mathrm{aq})$ in Duolite A-102 D

(Amount of the ion exchange resin in chloride form $=0.500 \mathrm{~g}$, volume of the oxalate ion solution $=100 \mathrm{~mL}$, temperature $=30.0{ }^{\circ} \mathrm{C}$ ).

\begin{tabular}{|c|c|c|c|c|c|c|c|}
\hline \multirow[t]{2}{*}{$\begin{array}{l}\text { Initial conc. of } \mathrm{C}_{2} \mathrm{O}_{4}{ }^{2-} \\
\text { ions in solution }(\mathrm{M})\end{array}$} & \multicolumn{2}{|c|}{$\begin{array}{l}\text { Equilibrium conc. in } \\
\text { solution }(\mathrm{M})\end{array}$} & \multicolumn{2}{|c|}{$\begin{array}{l}\text { Amount of the ions on } \\
\text { the resin meq. } / 0.500 \mathrm{~g}\end{array}$} & \multirow{2}{*}{$\begin{array}{c}\text { Apparent } \\
\text { equilibrium } \\
\text { constant } \mathrm{K}_{\text {app }}\end{array}$} & \multirow{2}{*}{$\frac{\mathrm{K}_{\text {std }}}{\mathrm{K}_{\mathrm{app}}}$} & \multirow{2}{*}{$=\frac{\left(\gamma_{\mathrm{R} 2 \mathrm{C} 2 \mathrm{O} 4}\right)}{\left(\gamma_{\mathrm{RCl}}\right)^{2}}$} \\
\hline & $\mathrm{C} \mathrm{Cl}^{-}$ & $\mathrm{C}_{\mathrm{C} 2 \mathrm{O} 4}{ }^{2-}$ & $\mathrm{C}_{\mathrm{RCl}}$ & $\mathrm{C}_{\mathrm{R} 2 \mathrm{C} 2 \mathrm{O} 4}$ & & & \\
\hline 0.007 & 0.0074 & 0.0026 & 0.46 & 0.370 & 27.6 & & 1.11 \\
\hline 0.008 & 0.0077 & 0.0034 & 0.43 & 0.385 & 26.5 & & 1.15 \\
\hline 0.009 & 0.0079 & 0.0042 & 0.41 & 0.395 & 25.0 & & 1.23 \\
\hline 0.010 & 0.0081 & 0.0051 & 0.39 & 0.405 & 23.9 & & 1.29 \\
\hline 0.015 & 0.0087 & 0.0109 & 0.33 & 0.435 & 17.2 & & 1.80 \\
\hline 0.020 & 0.0090 & 0.0172 & 0.30 & 0.450 & 13.2 & & 2.33 \\
\hline 0.030 & 0.0092 & 0.0266 & 0.28 & 0.460 & 9.3 & & 3.45 \\
\hline 0.050 & 0.0098 & 0.0466 & 0.22 & 0.490 & 8.5 & & 3.90 \\
\hline
\end{tabular}

Equilibrium constant in standard state $\left(\mathrm{K}_{\mathrm{std}}\right)=31.4$.

In absence of any method to determine the activity coefficients of the ions in the resin individually the best that can be done is to attempt to determine the quantity $\gamma_{\mathrm{R} 2 \mathrm{y}} /\left(\gamma_{\mathrm{Rx}}\right)^{2}$ and to determine the true equilibrium constant. In ionic equilibrium it is conventional to regard zero concentration as the standard state when the mean activity coefficient becomes unity. In the present situation however, such standard state can not be chosen for the ions in the resin because the ion exchange resin will always contains its capacity full of ions which can not be decreased.

No doubt the ions in the resin might all be univalent or all be divalent or partly univalent and partly divalent. In any case the resin contain ions to its full capacity. However, when the resin is entirely in the chloride form (univalent), its ionic strength will be much different from that when the resin is entirely in sulfate or oxalate (divalent) form. Therefore it is expected that the quantity $\gamma_{\mathrm{R} 2 \mathrm{y}} /\left(\gamma_{\mathrm{Rx}}\right)^{2}$ will vary according to what extent the resin is in the univalent and divalent ionic form.

In view of the above, it is found best to choose the ion exchange resin completely in univalent ionic form as the standard state and refer the resin at any other composition of the 
uni/divalent ions to this standard state. Therefore the apparent equilibrium constants calculated by the Eq. 8 have been plotted versus the equilibrium concentrations of the divalent ions in the solution (Figures 1,2). Lower the equilibrium concentration of the divalent ion lower would be its concentration in the resin and in the limiting case of zero equilibrium concentration of the divalent ion in the solution, the resin would be in its standard state. Therefore on extrapolating the above curve to zero equilibrium concentration of divalent ion in the solution, one obtains the equilibrium constant in the standard state, $\mathrm{K}_{\text {std. }}$. Having thus obtained the equilibrium constant in the standard state one can obtain the activity coefficient ratio of ions $\gamma_{\mathrm{R} 2 \mathrm{y}} /\left(\gamma_{\mathrm{Rx}}\right)^{2}$ at any finite equilibrium concentration of divalent ion in the solution as the ratio of $\mathrm{K}_{\text {std }} / \mathrm{K}_{\text {app }}$ The results of such calculations are presented in the Tables 5, 6 .

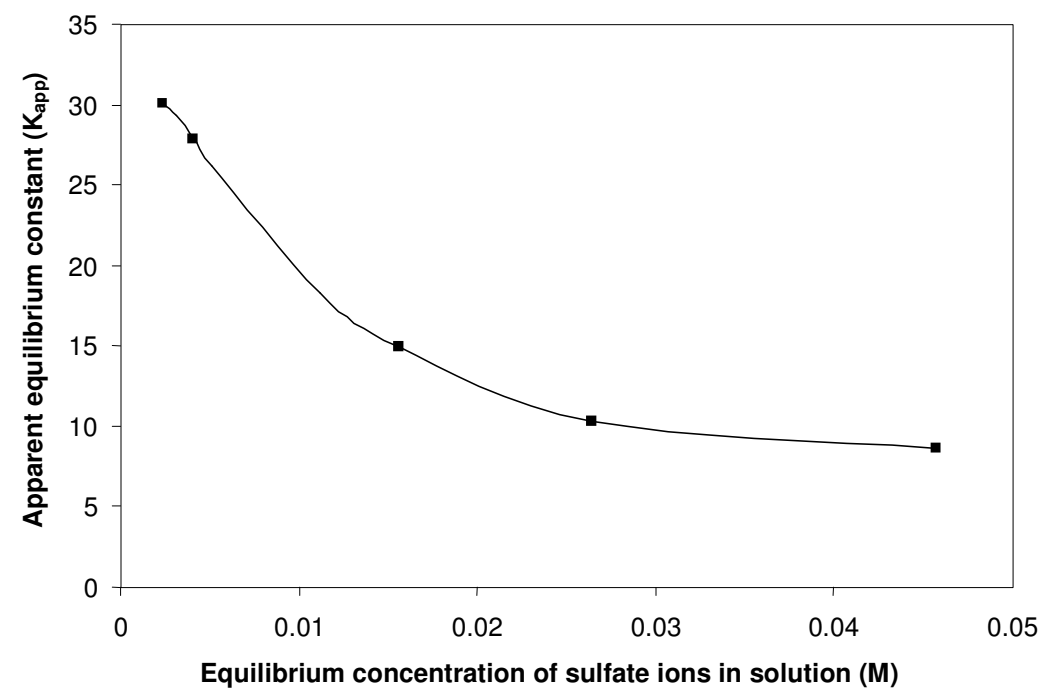

Figure 1. Variation of apparent equilibrium constant $\left(\mathrm{K}_{\mathrm{app}}\right)$ with equilibrium concentration of sulfate ions solution for uni-divalent ion exchange reaction:

$2 \mathrm{R}-\mathrm{Cl}+\mathrm{SO}_{4}{ }^{2-}{ }_{(\mathrm{aq})} \leftrightarrows \mathrm{R}_{2} \mathrm{SO}_{4}+2 \mathrm{Cl}_{(\mathrm{aq})}^{-}$using Duolite A-102 D resins

Amount of the ion exchange resin in chloride form $=0.500 \mathrm{~g}$, volume of the sulfate ion solution $=100 \mathrm{~mL}$, temperature $=30.0{ }^{\circ} \mathrm{C}$

It is significant that when the $\log \mathrm{K}_{\text {app }}$ is plotted against $1 / \mathrm{T}$, different slopes and hence different values of enthalpy of ion exchange reaction are obtained. However, a satisfactory linear graph with definite slope was obtained when $\log \mathrm{K}_{\text {std }}$ was plotted against $1 / \mathrm{T}$ giving a definite value of enthalpy of ion exchange reactions. This is an ample justification for the choice of standard state for equilibrium constant. Bonner and Pruett [16] studied the temperature effect on uni-univalent exchanges involving some divalent ions. In all divalent exchanges, the equilibrium constant decreases with rise in temperature resulting in exothermic reactions. However in the present investigation, for both the uni-univalent and uni-divalent exchange reactions the value of equilibrium constant increases with rise in temperature giving positive enthalpy value (Tables 3, 4, 7,8), indicating the endothermic ion exchange reactions. The low enthalpy and higher $\mathrm{K}$ values for $\mathrm{Cl}^{-} / \mathrm{I}^{-}$exchange as compared to that for $\mathrm{Cl}^{-} / \mathrm{Br}^{-}$exchange, indicate that the resins in chloride form are having more affinity for larger ionic size iodide ions 
in solution as compared to that for bromide ions also in the solution. Similarly, the K values for uni-bivalent exchange reactions are higher than that for uni-univalent exchange reactions, indicating that the affinity of resins in chloride form for the ions in solution increases with increase in ionic charge of the exchangeable ions in the solution.

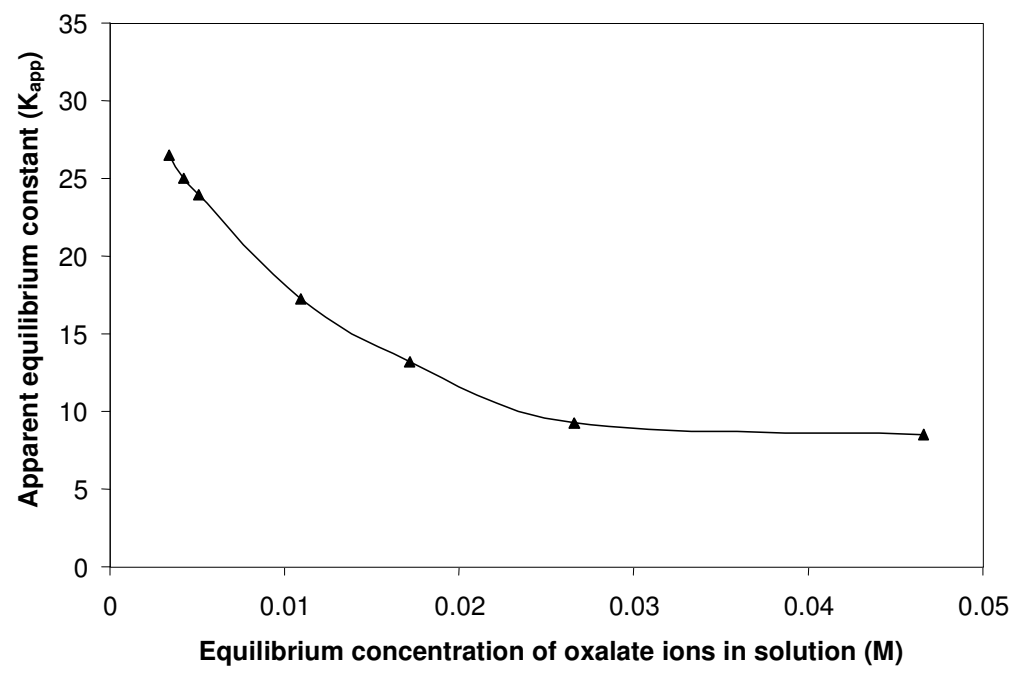

Figure 2. Variation of apparent equilibrium constant $\left(\mathrm{K}_{\mathrm{app}}\right)$ with equilibrium concentration of oxalate ions solution for uni-divalent ion exchange reaction:

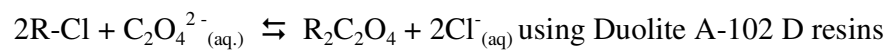

Amount of the ion exchange resin in chloride form $=0.500 \mathrm{~g}$, volume of the oxalate ion solution $=100 \mathrm{~mL}$, temperature $=30.0{ }^{\circ} \mathrm{C}$.

Table 7. Effect of temperature on equilibrium constant in standard state $\left(\mathrm{K}_{\text {std. }}\right)$ for uni - divalent ion exchange reaction

$2 \mathrm{R}-\mathrm{Cl}+\mathrm{SO}_{4}^{2-}{ }_{(\mathrm{aq})}^{-} \leftrightarrows \mathrm{R}_{2} \mathrm{SO}_{4}+2 \mathrm{Cl}_{\text {(aq) }}^{-}$in Duolite A-102 D

(Amount of ion exchange resin in chloride form $=0.500 \mathrm{~g}$, volume of $\mathrm{SO}_{4}{ }^{2-}$ ion solution $=100 \mathrm{~mL}$ ).

\begin{tabular}{|c|l|l|l|l|}
\hline Temperature ${ }^{\circ} \mathrm{C}$ & 30.0 & 35.0 & 40.0 & 45.0 \\
\hline $\mathrm{K}_{\text {std. }}$ & 32.7 & 44.7 & 51.9 & 60.0 \\
\hline
\end{tabular}

Slope of graph $\log \mathrm{K}_{\text {std }} v s$. temperature (Kelvin) $1 / \mathrm{T} \times 10^{-3}=-1249.0$. Enthalpy change of the ion exchange reaction $=23.9 \mathrm{~kJ} / \mathrm{mol}$.

Table 8. Effect of temperature on equilibrium constant in standard state $\left(\mathrm{K}_{\mathrm{std}}\right)$ for uni-divalent ion exchange reaction in Duolite A-102 D

$2 \mathrm{R}-\mathrm{Cl}+\mathrm{C}_{2} \mathrm{O}_{4}{ }^{2-}{ }_{(\mathrm{aq})} \leftrightarrows \mathrm{R}_{2} \mathrm{C}_{2} \mathrm{O}_{4}+2 \mathrm{Cl}^{-}{ }^{-}$(aq.)

(Amount of ion exchange resin in chloride form $=0.500 \mathrm{~g}$, volume of oxalate ion solution $=100 \mathrm{~mL}$ ).

\begin{tabular}{|c|c|c|c|c|}
\hline Temperature ${ }^{\circ} \mathrm{C}$ & 30.0 & 35.0 & 40.0 & 45.0 \\
\hline $\mathrm{K}_{\text {std. }}$ & 31.4 & 42.4 & 48.9 & 56.2 \\
\hline
\end{tabular}

Slope of graph $\log \mathrm{K}_{\mathrm{std}} v s$. temperature (Kelvin) $1 / \mathrm{T} \times 10^{-3}=-1198.1$. Enthalpy change of the ion exchange reaction $=22.9 \mathrm{~kJ} / \mathrm{mol}$. 
In the present study, a semi-micro burette having an accuracy of $0.02 \mathrm{~mL}$ was used in the titrations against silver nitrate solution. The titration readings were accurate to $\pm 0.02 \mathrm{~mL}$. Considering the magnitude of the titre values, the average equilibrium constants reported in the experiment are accurate to $\pm 3 \%$.

\section{REFERENCES}

1. Andreev, N.N; Kuznetsov, Yu.I. Russ. J. Phys. Chem. 1990, 64, 1537.

2. Bhargava, A.; Janardanan, C. Indian J. Chem. 1997, 36A, 624.

3. Muraviev, D.; Gonzalo, A.; Valiente, M. Anal. Chem. 1995, 67, 3028.

4. Boyd, G.E.; Vaslow, F.; Lindenbaum, S. J. Phys. Chem. 1967, 71, 2214.

5. Duncan, J.F. Aus. J. Chem. Soc. 1955, 8, 1.

6. Boyd, G.E.; Vaslow, F.; Lindenbaum, S. J. Phys. Chem. 1964, 68, 590.

7. Schwarz, A.; Boyd, G.E. J. Phys. Chem. 1965, 69, 4268.

8. Gamayunov, N.I. Russ. J. Phys. Chem. 1990, 64, 1787.

9. Boyd, G.E.; Myers, G.E. J. Phys. Chem. 1956, 60, 521.

10. Bonner, O.D. J. Phys. Chem. 1955, 59, 719.

11. Bonner, O.D. J. Phys. Chem. 1954, 58, 318.

12. Lindenbaum, S.; Jumper, C.F.; Boyd, G.E. J. Phys. Chem. 1959, 63, 1924.

13. Kraus, K.A.; Raridon, R.J. J. Phys. Chem. 1959, 63, 1901.

14. Bonner, O.D.; Payne, W.H. J. Phys. Chem. 1954, 58, 183.

15. Argersinger, W.J.; Davidson, A.W. J. Phys. Chem. 1952, 56, 92.

16. Bonner, O.D.; Pruett, R.R. J. Phys. Chem. 1959, 63, 1420.

17. Bonner, O.D.; Livingston, F.L. J. Phys. Chem. 1956, 60, 530.

18. Bonner, O.D.; Smith, L.L. J. Phys. Chem. 1957, 61, 326.

19. Bonner, O.D.; Jumper, C.F.; Rogers, O.C. J. Phys. Chem. 1958, 62, 250.

20. Bonner, O.D.; Smith, L.L. J. Phys. Chem. 1957, 61, 1614.

21. Kielland, J. J. Soc. Chem. Ind. 1935, 54, 232 T.

22. Vanselow, A.P. J. Am. Chem. Soc. 1932, 54, 1307.

23. Gaines (Jr.) G.L.; Thomas, H.C. J. Chem. Phys. 1953, $21,714$.

24. Kraus, K.A.; Raridon, R.J.; Holcomb, D.L.; Chromatogr. J. 1960, 3, 178.

25. Lokhande, R.S.; Singare, P.U. Asian J. Chem. 1998, 10, 898.

26. Lokhande, R.S.; Singare, P.U. Chem. Environ. Res. 1998, 7, 283.

27. Lokhande, R.S.; Singare, P.U. Orient. J. Chem. 1998, 14, 247.

28. Lokhande, R.S.; Singare, P.U. Indian J. Chem. 1999, 38 A, 87.

29. Lokhande, R.S.; Singare, P.U. Asian J. Chem. 2001, 13, 43.

30. Bonner, O.D.; Dickel, G.; Brummer, H. Z. Physik. Chem. 1960, 25, 81.

31. Starodinet, G.L.; Soldatov, V.S.; Krylova, A.A. Russ. J. Phys. Chem. 1967, 41, 194.

32. Lokhande, R.S.; Singare, P.U. Asian J. Chem. 2003, 15, 33.

33. Lokhande, R.S.; Singare, P.U. Asian J. Chem. 1998, 10, 890. 